\title{
Using qualitative research within complex interventions: lessons from the podosa (prevention of diabetes and obesity in South Asians) trial
}

\author{
Zoe Morrison*, Anne Douglas, Raj Bhopal, Aziz Sheikh \\ From 2nd Clinical Trials Methodology Conference: Methodology Matters \\ Edinburgh, UK. 18-19 November 2013
}

\section{Background}

We conducted a qualitative study to gain insight into the high retention rate and variable outcomes achieved in the 3-year PODOSA (Prevention of Diabetes and Obesity in South Asians) family-based cluster randomised controlled trial of a dietitian-delivered lifestyle modification intervention.

\section{Methods}

We interviewed 21 trial participants and family volunteers following trial completion. Purposive sampling ensured representation of the diversity within the trial population. Data were thematically analysed. Findings were shared with trial dietiticans once the trial had closed.

\section{Findings}

Many participants were aware of their family history of diabetes and attracted by the availability of information and monitoring. Offering home or clinic-based interventions, communication in the participant's chosen language(s) and excellent relationships between participants and dieticians contributed to retention. Adaptations in food choices were accommodated by participants, although community and faith based considerations made consistent adherence challenging. Participants found increasing their level of physical activity difficult given other demands, including long working hours, physically demanding employment and domestic commitments.

\section{Interpretation}

Undertaking qualitative research allowed in-depth insight into participation, retention and adherence in the PODOSA trial. The main benefit participants sought

The University of Edinburgh, Edinburgh, UK was information regarding diabetes. Home-based interventions and continuity in dieticians were included in trial design, but it was not anticipated that these relationships would contribute so greatly to retention. Adaptations in food choices were not felt to be an extra burden upon participants but were made more difficult due to cultural considerations. Increasing levels of physical activity were felt to be an additional burden, again augmented by cultural considerations.

Published: 29 November 2013

doi:10.1186/1745-6215-14-S1-P101

Cite this article as: Morrison et al:: Using qualitative research within complex interventions: lessons from the podosa (prevention of diabetes and obesity in South Asians) trial. Trials 2013 14(Suppl 1):P101.

Submit your next manuscript to BioMed Central and take full advantage of:

- Convenient online submission

- Thorough peer review

- No space constraints or color figure charges

- Immediate publication on acceptance

- Inclusion in PubMed, CAS, Scopus and Google Scholar

- Research which is freely available for redistribution

\section{The University of Edinburgh, Edinburgh, UK}

(c) 2013 Morrison et al; licensee BioMed Central Ltd. This is an Open Access article distributed under the terms of the Creative 